\title{
Investigation of Nutrient Contents in Jujube and Its Orchard Soils under Pesticide-Free Cultivation in Boeun Region
}

\author{
Gyeong-Ja Lee*, Bo-Goo Kang, Ki-Sik Kim, Ik-Hwan Kim, Jong-U Han, and Hyun-Zoo Kim \\ Chungbuk Agricultural Research and Extension Services, Cheongweon 363-883, Korea
}

(Received: November 5 2013, Accepted: November 15 2013)

To obtain the useful data related to optimum nutrient management technique for pesticides-free jujube cultivation, nutrient contents of jujube leaves and fruits and the selected chemical properties of jujube orchard soils were investigated at 9 different orchards with pesticides-free cultivation in Boeun, Chungbuk, Korea. Soil and jujube leaf samples were collected from the different orchards in July and October, and jujube fruit samples were taken in October, 2012. Soil available $\mathrm{P}_{2} \mathrm{O}_{5}$ contents in the optimum level for jujube cultivation were $11 \%$ and $33 \%$ of total samples in July and October, respectively, but $56 \%$ of total samples was higher than the optimum level in both July and October. Exchangeable $K$ and Ca ion contents were $44 \%$ and $67 \%$ of total samples, respectively, in both July and October, whereas exchangeable Mg ion content was $100 \%$ and $\mathbf{5 6 \%}$ of total samples in July and October, respectively. Nutrient contents in jujube leaves were higher than those in fresh fruits. In addition, total nitrate, potassium and magnesium contents in the jujube leaves were higher in the samples collected in July than in October.

Key words: Jujube, Chemical property, Pesticides-free cultivation, Jujube orchard

Selected chemical properties of soils in pesticide-free cultivated jujube orchard fields.

\begin{tabular}{|c|c|c|c|c|c|c|c|}
\hline \multirow{2}{*}{ Sampling period } & \multirow{2}{*}{$\mathrm{pH}$} & \multirow{2}{*}{$\mathrm{EC}$} & \multirow{2}{*}{$\mathrm{OM}$} & \multirow{2}{*}{$\begin{array}{l}\text { Avail. } \\
\mathrm{P}_{2} \mathrm{O}_{5}\end{array}$} & \multicolumn{3}{|c|}{ Exch. cation } \\
\hline & & & & & $\mathrm{K}$ & $\mathrm{Ca}$ & $\mathrm{Mg}$ \\
\hline & $1: 5$ & $\mathrm{dS} \mathrm{m}^{-1}$ & $\mathrm{~g} \mathrm{~kg}^{-1}$ & $\mathrm{mg} \mathrm{kg}^{-1}$ & (----------- & $\mathrm{cmol}_{\mathrm{c}} \mathrm{kg}$ & - \\
\hline Jul. & $6.3 \pm 0.66^{\dagger}$ & $0.64 \pm 0.24$ & $24 \pm 6.8$ & $594 \pm 415$ & $0.83 \pm 0.46$ & $5.1 \pm 2.5$ & $1.6 \pm 0.21$ \\
\hline Oct. & $6.5 \pm 0.41$ & $0.59 \pm 0.33$ & $30 \pm 12$ & $714 \pm 498$ & $0.83 \pm 0.76$ & $5.8 \pm 2.1$ & $1.9 \pm 0.43$ \\
\hline
\end{tabular}

${ }^{\dagger}$ Average \pm standard deviation. 


\section{Introduction}

우리나라의 대추에 관한 연구는 1970년대부터 80년대까지 우수품종 선발연구 (Kim et al., 1980; Kim et al., 1981; Kim et al., 1988)에 주력하여 오다가 90년대에 접어들면서 병해충 방제연구 (Bak and La, 1993; Jee et al., 1998)와 저장연구 (An and Lee, 1997; Chung et al., 1995; Park et al., 2006)가 수행되었다. 건강에 관심이 많아지면서부터 2010년경부터 대추의 영양성분 및 유효성분에 대한 활성연구 (Hong et al., 2010; Hong et al., 2012; Kim et al., 2011)와 건조에 관한 연구 (Hong et al., 2012; Shin et al., 1999)가 수행되었다. 지금까지 대추에 관한 연구는 일부학자들에 의해 제한된 범 위에서 수행되었을 뿐 활발하게 진행되지 않았다. 최근 들어 보 은지역을 중심으로 생대추가 고소득 원예과수로 부각되면서 재배에 관한 연구의 움직임을 보이고 있다. 산림청 통계자료 (KFS, 2012)에 따르면 대추 생산량은 경산이 가장 많고, 이어 군위, 청도, 보은 순으로 많으나 생산액은 경산에 이어 보은이 두 번째로 많다. 이러한 현상은 보은군의 경우에는 다른 지역과는 달리 거의 대부분 생대추로 생산하여 고가로 판매하기 때문 일 것이다. 생대추로 유통되기 위해서는 무농약이나 유기재배로 생산하는 것이 우선일 것이나 생산단지가 집약화 되어있는 주산지에서는 쉽지 않은 방법이다. 더욱이 대추는 과실 특 성상 과실품질을 높이면서 농약으로부터 안전성을 유지하 기 위하여 봉지 재배를 할 수 있는 여건이 되지 않는다. 따 라서 무농약 재배나 혹은 유기재배가 더욱 필요한 작목이라 할 수 있다. 보은지역의 대추 재배농가 중 일부농가는 저농 약농산물 인증을, 일부농가는 무농약농산물 인증을 받아 재 배관리 하고 있으나 저농약농산물 인증제도는 2015년부터 완전히 폐지될 예정이다. 따라서 저농약농산물 인증 과원이 유기 또는 무농약농산물 인증 농가로 전환하는 것과 현재 무농약농산물 인증을 받아 관리하는 과원을 순조롭게 유기 재배로 전환 할 수 있도록 유도할 필요가 있다. 다른 과종의 경우 무농약재배나 혹은 유기재배에 관한 연구 (Choi et. al., 2011; Choi et. al., 2010; Kim et. al., 2011)가 어느정 도 수행되어 왔으나, 대추에 관한 연구는 전혀 수행된 바가 없다. 따라서 보은지역의 대추 무농약재배지의 토양 화학적 특성뿐만 아니라 대추의 잎과 과실 중 양분함량을 조사하여 무농약 대추재배로 인증된 과원의 적절한 양분관리를 위한 기초자료를 얻고자 본 조사를 실시하였다.

\section{Materials and Methods}

시료채취는 보은군 일원 무농약 대추재배지를 대상으로 하였다. 2012년도 보은군 전역의 대추 유기재배인증 농가는 없었고, 무농약인증을 받은 경우가 총 10 농가였다. 그 중 9 농가를 대상으로 무농약인증 재배지 토양과 대추의 잎 및
과실을 채취하여 분석에 이용하였다. 토양과 잎의 시료는 2012 년 7월과 10월에 채취하였고, 과실은 10월에 채취하였다. 토양시료 채취방법은 한 지점 당 표토 (0 20cm 깊이)에서 15 곳 이상을 채취하여 고루 섞은 후 일부를 취하여 분석에 이용하였다.

토양 및 잎의 양분함량 분석은 농업과학기술원 토양 및 식물체 분석법에 준하여 실시하였다 (NIAST, 2000). 토양의 $\mathrm{pH}$ 와 $\mathrm{EC}$ 는 시료와 증류수를 $1: 5$ 의 비율로 혼합하여 30 분간 진탕한 후, $\mathrm{pH}$ 는 $\mathrm{pH}$ meter (Radiometer M-92, Denmark) 로 측정하였고, $\mathrm{EC}$ 는 Conductivity meter (YSI-32, Ohio, USA)로 측정하여 5 배한 값으로 나타내었으며, 유기물 함량 은 Tyurin법, 유효인산은 Lancaster 법으로 비색계 (Varian Cary 100, Australia)를 이용하여 측정하였다. 치환성 K, Ca 및 $\mathrm{Mg}$ 이온의 함량은 $1 \mathrm{~N}$ ammonium acetate로 침출하여 ICP (Varian Vista-Pro, Australia)로 분석하였다. 대추의 잎 과 과실의 양분함량은 시료를 $70^{\circ} \mathrm{C}$ 에서 건조시킨 후 분쇄하여 분쇄된 시료를 산 분해용액 $\left(\mathrm{HClO}_{4}: \mathrm{H}_{2} \mathrm{SO}_{4}=10: 1\right)$ 으로 습식 분해하여 전질소는 Kjeldahl법으로, 인산은 Vanadate법으로 그리고 치환성 $\mathrm{K}, \mathrm{Ca}$ 및 $\mathrm{Mg}$ 이온은 ICP (Varian Vista-Pro, Australia)로 분석하였다.

\section{Results and Discussion}

토양의 화학적 함량 2012년에 보은군 일원에서 대추 과원을 운영하는 1,200 여 농가 중에서 유기재배인증 농가는 없었다. 그러나 무농약 재배가 인증된 경우는 10 농가였고, 그 중 9농가에서 조사를 실시하였다. 이들 농가는 병해충방 제 및 시비방법에 관하여 각 농가 간에 정보를 공유하고 있 었고, 액비 및 친환경 자재를 공동으로 만들어서 사용하고 있었다. 대추 무농약재배 인증을 받아 관리하는 과원의 토 양에 대한 양분 현황을 파악하기 위하여, 이들 9 지점에서 과 실 착과기인 7월과 수확기인 10월에 토양을 채취하여 화학 성을 조사하였다 (Table 1). 7월에 조사된 토양의 평균 화학적 함량은 $\mathrm{pH}$ 는 $6.3, \mathrm{EC}$ 는 $0.64 \mathrm{dS} \mathrm{m}^{-1}$, 유기물은 $24 \mathrm{~g} \mathrm{~kg}^{-1}$, 유효인산은 $594 \mathrm{mg} \mathrm{kg}^{-1}$, 치환성 $\mathrm{K}$ 이온은 $0.83 \mathrm{cmol}_{\mathrm{c}} \mathrm{kg}^{-1}$, 치환성 $\mathrm{Ca}$ 이온은 $5.1 \mathrm{cmol}_{\mathrm{c}} \mathrm{kg}^{-1}$, 치환성 $\mathrm{Mg}$ 이온은 $1.6 \mathrm{cmol}_{\mathrm{c}} \mathrm{kg}^{-1}$ 이었다. 10 월에 조사된 토양의 평균 화학적 함량은 $\mathrm{pH}$ 는 $6.5, \mathrm{EC}$ 는 $0.59 \mathrm{dS} \mathrm{m}$, 유기물은 $30 \mathrm{~g} \mathrm{~kg}^{-1}$, 유효인산은 $714 \mathrm{mg} \mathrm{kg}^{-1}$, 치환성 $\mathrm{K}$ 이온은 $0.83 \mathrm{cmol}_{\mathrm{c} \mathrm{kg}} 1^{-1}$, 치환성 $\mathrm{Ca}$ 이온은 $5.8 \mathrm{cmol}_{\mathrm{c}} \mathrm{kg}^{-1}$, 치환성 $\mathrm{Mg}$ 이온은 $1.9 \mathrm{cmol}_{\mathrm{c}} \mathrm{kg}^{-1}$ 이 었다. 조사지점간에 양분함량이 상당히 달랐기 때문에 유의 성은 인정되지 않았으나, 평균값만을 비교하면 10 월 토양의 양분함량이 7월 토양에 비하여 유효인산, 치환성 $\mathrm{Ca}$ 이온 및 치환성 $\mathrm{Mg}$ 이온이 높았다. 이것은 8월 이후 과실비대시기에 나무에 필요이상으로 양분을 추가 시용하였기 때문이라 생 각된다. 조사농가의 설문조사에 따르면 과실 착과 이후인 7 
Table 1. Selected chemical properties of soils in pesticide-free cultivated jujube orchard fields.

\begin{tabular}{ccccccccc}
\hline \hline \multirow{2}{*}{$\begin{array}{c}\text { Sampling } \\
\text { period }\end{array}$} & & $\mathrm{pH}$ & $\mathrm{EC}$ & $\mathrm{OM}$ & $\begin{array}{c}\text { Avail. } \\
\mathrm{P}_{2} \mathrm{O}_{5}\end{array}$ & \multicolumn{3}{c}{ Exch. cation } \\
\hline \multirow{3}{*}{ Jul. } & & $1: 5$ & $\mathrm{dS} \mathrm{m}$ & $\mathrm{g} \mathrm{kg}^{-1}$ & $\mathrm{mg} \mathrm{kg}^{-1}$ & & $\mathrm{Ca}$ & $\mathrm{Mg}$ \\
& Avg. & $6.3 \pm 0.66^{\dagger}$ & $0.64 \pm 0.24$ & $24 \pm 6.8$ & $594 \pm 415$ & $0.83 \pm 0.46$ & $5.1 \pm 2.5$ & $1.6 \pm 0.21$ \\
& Min. & 5.0 & 0.36 & 13 & 224 & 0.38 & 1.6 & 1.1 \\
& Max. & 7.3 & 1.12 & 35 & 1319 & 1.82 & 10.8 & 1.7 \\
\hline \multirow{2}{*}{ Oct. } & Avg. & $6.5 \pm 0.41$ & $0.59 \pm 0.33$ & $30 \pm 12$ & $714 \pm 498$ & $0.83 \pm 0.76$ & $5.8 \pm 2.1$ & $1.9 \pm 0.43$ \\
& Min. & 5.8 & 0.23 & 17 & 253 & 0.25 & 3.0 & 1.3 \\
& Max. & 7.0 & 1.17 & 51 & 1769 & 2.71 & 10.5 & 2.6 \\
\hline
\end{tabular}

${ }^{\dagger}$ Average \pm standard deviation.
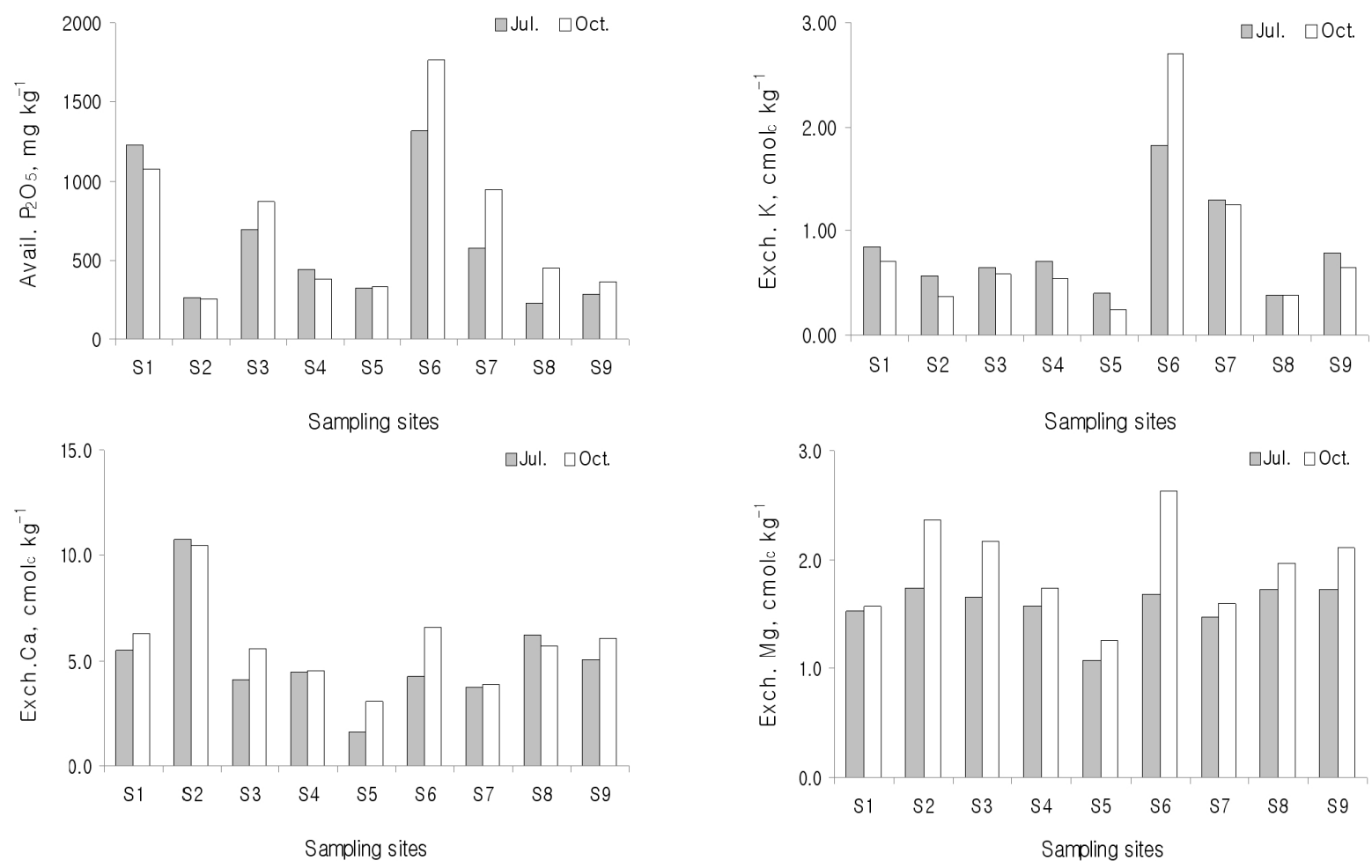

Fig. 1. Contents of available $\mathrm{P}_{2} \mathrm{O}_{5}$ and exchangeable $\mathrm{K}, \mathrm{Ca}$, and $\mathrm{Mg}$ ions in soils of different pesticide-free jujube fields.

월 말에서 8월에 걸쳐 추비를 사용하였고, 과실크기를 키우 기 위하여 마그네슘 및 칼슘을 시용하였다. 또한, 화학비료 를 $1 / 3$ 만큼 감량하였으므로 토양 중에 양분이 부족할 것이 라고 생각하여 퇴비 및 동물뼈 등 각종 농부산물 뿐 만 아니 라 시중에서 판매되는 친환경 재료를 과량으로 사용하였다 (자료 미제시). 조사지점간에 양분함량이 상당히 다른 것은 각 지점별로 대추과원의 토양 환경이 다를 뿐 만 아니라, 공 동으로 제조하여 사용하는 자재와는 별도로 농가별로 각자 양분관리를 하고 있음을 나타낸다. Kim et al. (1989)은 영 남지역 대추 주산지인 경산, 밀양, 청도, 상주의 대추재배지 토양 화학적 특성을 조사한 결과, 지역 간에 상당한 차이가 있으며 경산지역이 밀양, 청도, 상주에 비하여 다소 높다고 보고하였다. 이들 보고에 의하면 경산지역의 대추과원 토양
화학적 평균 함량은 유기물 $35 \mathrm{~g} \mathrm{~kg}^{-1}$, 유효인산 $815 \mathrm{mg} \mathrm{kg}^{-1}$, 치환성 $\mathrm{K}$ 이온은 $0.82 \mathrm{cmol}_{\mathrm{c}} \mathrm{kg}^{-1}$, 치환성 $\mathrm{Ca}$ 이온은 $6.24 \mathrm{cmol}_{\mathrm{c}} \mathrm{kg}^{-1}$, 치환성 $\mathrm{Mg}$ 이온은 $1.25 \mathrm{cmol}_{\mathrm{c}} \mathrm{kg}^{-1}$ 이고, 이들 네 지역에 대 한 평균 함량은 $\mathrm{pH} 5.7$, 유효인산 $563 \mathrm{mg} \mathrm{kg}^{-1}$, 치환성 $\mathrm{K}$ 이 온 $0.68 \mathrm{cmol}_{\mathrm{c}} \mathrm{kg}^{-1}$, 치환성 $\mathrm{Ca}$ 이온 $5.03 \mathrm{cmol}_{\mathrm{c}} \mathrm{kg}^{-1}$, 치환성 $\mathrm{Mg}$ 이온 $0.84 \mathrm{cmol}_{\mathrm{c}} \mathrm{kg}^{-1}$ 이라고 보고 하였다. 본 조사에서는 치환성 $\mathrm{Mg}$ 이온을 제외한 모든 성분이 경산지역에 비하여 낮았지만, 네 지역의 평균값에 비하여 모든 성분이 높았다. 이러한 결과는 과실을 크게 키우기 위한 과다 시비 뿐 만 아 니라 화학비료를 관행재배보다 적게 시용하여 양분이 적다 는 생각에 의한 투입자재 과다 시용 때문이라 예상된다. 본 조사에서 10 월에 채취한 토양의 평균 양분함량이 7 월에 채 취한 토양에 비하여 높게 측정되었는데, 10 월에 조사한 지 
점 모두 양분함량이 높아졌는지를 파악하기 위하여 각각 지 점별로 7월과 10월의 토양 양분 함량을 비교 분석하였다 (Fig. 1). 유효인산은 조사지점중 6 지점에서, 치환성 $\mathrm{Ca}$ 이온은 7 지점에서, 치환성 $\mathrm{Mg}$ 이온은 9 지점에서 10 월에 채취한 토양 이 7월에 채취한 토양에 비하여 높았다. 그러나 치환성 $\mathrm{K}$ 이 온은 8 개지점이 10 월에 채취한 토양이 7 월 토양에 비하여 낮았다. 따라서 10 월 수확기 토양의 평균 양분함량이 7 월에 비하여 높은 것은 치환성 $\mathrm{K}$ 를 제외하고는 대부분의 농가에 서 더 높았기 때문이다. 치환성 $\mathrm{Ca}$ 이온과 치환성 $\mathrm{Mg}$ 이온이 10 월에 높아진것은 대부분의 대추재배농가에서 과실 비대 기에 시용하였기 때문이라 생각되나, 토양중 인산함량이 높 아진 것에 대해서는 조사가 필요할 것이라 보여진다.

각 성분 별 조사 지점의 적정분포율 Fig. 2 와 같다. $\mathrm{pH}$ 의 적정범위 (6.0 6.5)의 분포율은 7월 및 10월 모두 $44 \%$ 이었 고, $\mathrm{pH} 6.0$ 이하 분포율은 7 월과 10 월 각각 $22 \%$ 및 $11 \%$ 이
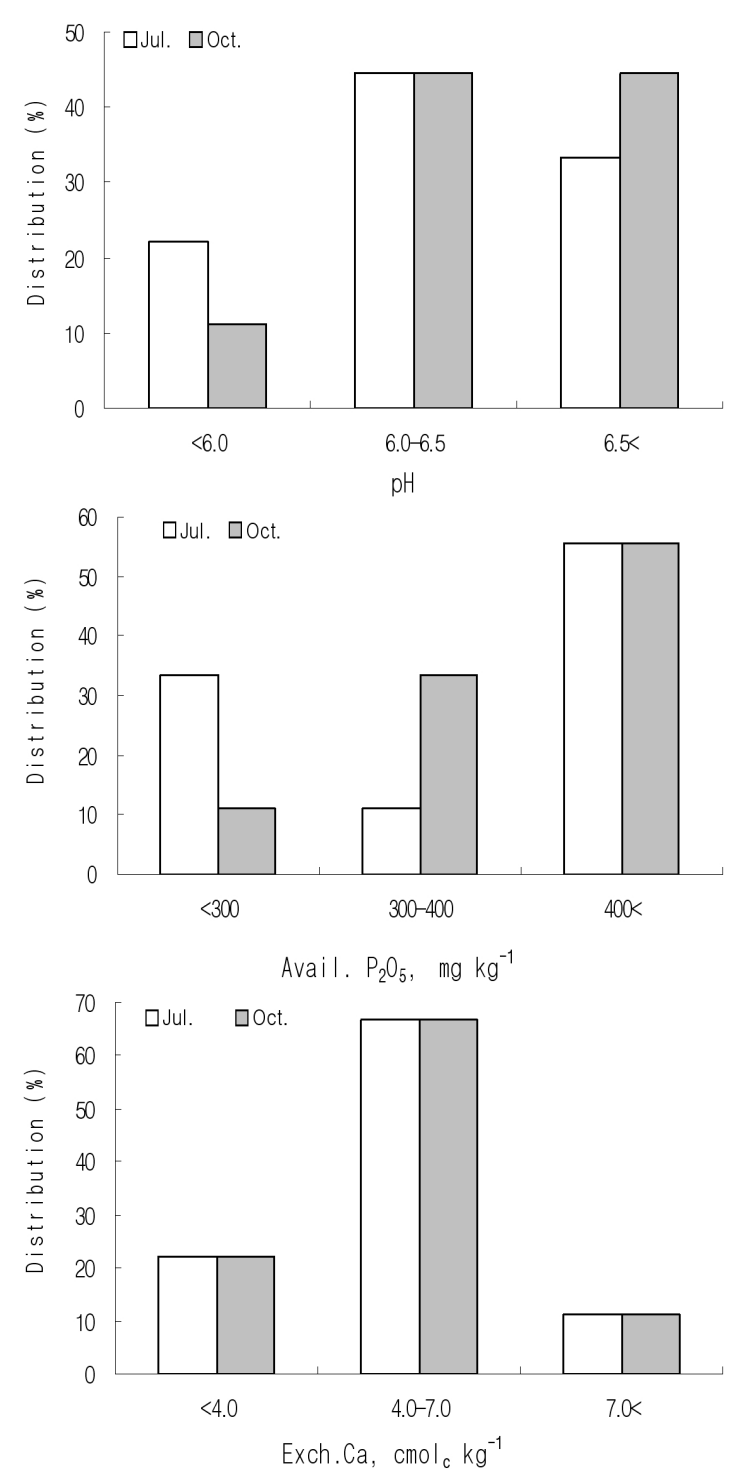

었으며, pH 6.5 이상 분포율은 각각 $33 \%$ 및 $44 \%$ 이었다. 염 류농도는 7월과 10월 모두 $2.0 \mathrm{dS} \mathrm{m}^{-1}$ 미만으로 적정범위 내에 있었다. 유효인산의 적정범위 (300 400 mg kg-1) 분포 율은 7월 및 10월에 각각 $11 \%$ 및 $33 \%$ 이었고, $300 \mathrm{mg} \mathrm{kg}^{-1}$ 미만의 분포율은 각각 $33 \%$ 및 $11 \%$ 이었다. $400 \mathrm{mg} \mathrm{kg}^{-1}$ 초 과 분포율은 7 월 및 10 월 모두 $56 \%$ 이었으나, 10 월에 채취한 토양에서 7월에 채취한 토양에 비하여 $300 \mathrm{mg} \mathrm{kg}^{-1}$ 미만 분 포율은 줄어들고, 적정 범위 $\left(300 ~ 400 \mathrm{mg} \mathrm{kg}^{-1}\right.$ )내의 분포율 이 증가함으로서 10 월에 채취한 토양의 평균함량이 7 월에 채취한 토양의 평균함량에 비하여 높아진 것이다. 치환성 $\mathrm{K}$ 이온의 적정범위 $\left(0.4 \sim 0.8 \mathrm{cmol}_{\mathrm{c}} \mathrm{kg}^{-1}\right)$ 분포율은 7 월과 10 월 에 채취한 토양 모두 $44 \%$ 이었고, $0.4 \mathrm{cmol}_{\mathrm{c} \mathrm{kg}}{ }^{-1}$ 미만 분포 율은 각각 $22 \%$ 및 $33 \%$ 이었으며, $0.8 \mathrm{cmol}_{\mathrm{c}} \mathrm{kg}^{-1}$ 초과 분포 율은 각각 $33 \%$ 및 $22 \%$ 이었다. 평균 치환성 $\mathrm{K}$ 이온 함량이 7 월과 10월에서 $0.83 \mathrm{cmol}_{\mathrm{c}} \mathrm{kg}^{-1}$ 로 같았지만 (Table 1), 10월
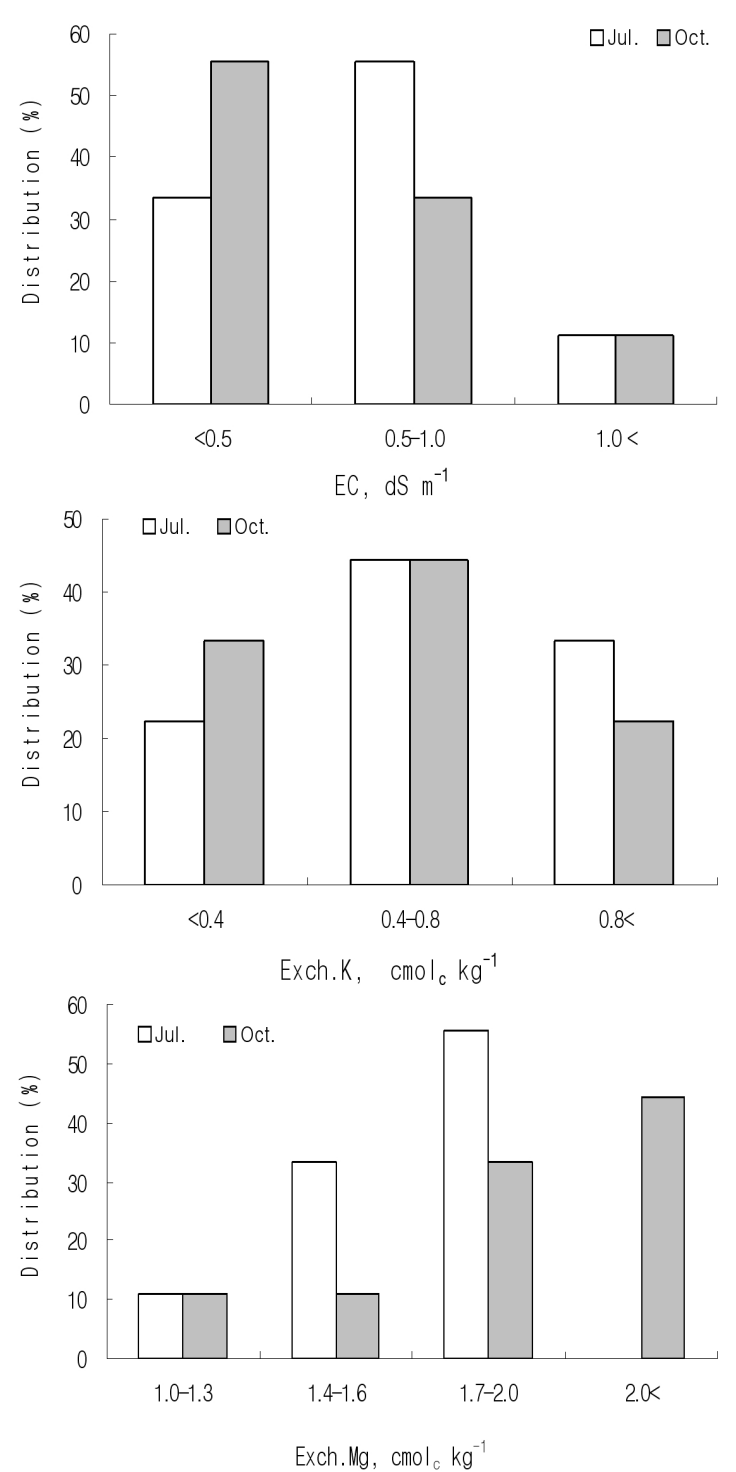

Fig. 2. Distribution of the different ranges of soil pH, EC, available $\mathrm{P}_{2} \mathrm{O}_{5}$ content and exchangeable $\mathrm{K}$, Ca and Mg ion contents in soils collected from pesticide-free cultivated jujube fields. 
에 채취한 토양에서 $0.4 \mathrm{cmol}_{\mathrm{c} \mathrm{kg}} \mathrm{kg}^{-1}$ 미만 분포율은 증가하였 고, $0.8 \mathrm{cmol}_{\mathrm{c}} \mathrm{kg}^{-1}$ 초과 분포율은 감소하였다. 따라서 치환 성 K이온은 조사지점 대부분이 10월에 채취한 토양에서 7월 에 채취한 토양에 비하여 감소했다고 볼 수 있다. 이것은 Fig. 2 의 결과와 일치한다. 치환성 $\mathrm{Ca}$ 이온의 적정범위 $\left(4.0 \sim 7.0 \mathrm{cmol}_{\mathrm{c}}\right.$ $\left.\mathrm{kg}^{-1}\right)$ 분포율은 7월과 10월에 채취한 토양 모두 $67 \%$ 이었고 $4.0 \mathrm{cmol}_{\mathrm{c}} \mathrm{kg}^{-1}$ 미만분포율은 22\%이었으며, $7.0 \mathrm{cmol}_{\mathrm{c}} \mathrm{kg}^{-1}$ 초과율은 $11 \%$ 이었다. 치환성 $\mathrm{Mg}$ 이온의 적정범위 (1.0 2.0 $\left.\mathrm{cmol}_{\mathrm{c}} \mathrm{kg}^{-1}\right)$ 분포율은 7월에 조사된 토양 $100 \%$ 가 적정 범위 내에 있었으나, 10 월에 조사된 토양에서는 $56 \%$ 가 적정 범위 내에 있었고, $44 \%$ 는 적정범위를 초과하였다. 이상의 결과 에서와 같이 유효인산은 7월 및 10월에 채취한 토양의 $56 \%$ 가 적정범위를 초과하였고, 치환성 $\mathrm{K}$ 이온은 7월에 채취한 토양에서는 $33 \%, 10$ 월에 채취한 토양에서는 $22 \%$ 가 적정범 위를 초과함으로 지속적 관리가 필요하다. 치환성 $\mathrm{Mg}$ 이온 은 과실 착과기 이후 과량의 시용으로 인하여 경시적으로 토양함량이 증가한 것으로 생각되며 추적연구가 필요하다 고 판단된다.

잎 및 과실중 무기성분 함량 과실 착과기인 7월과 수 확기인 10월에 대추 잎의 무기성분 함량을 조사하였다(Table 2). 7 월에 채취한 대추 잎의 평균 $\mathrm{T}-\mathrm{N}$ 은 $26.1 \mathrm{~g} \mathrm{~kg}^{-1}$ 이었고, $\mathrm{P}$ 는 $2.2 \mathrm{~g} \mathrm{~kg}^{-1}, \mathrm{~K}$ 은 $23.2 \mathrm{~g} \mathrm{~kg}^{-1}$, $\mathrm{Ca}$ 은 $17.7 \mathrm{~g} \mathrm{~kg}^{-1}, \mathrm{Mg}$ 은 $3.1 \mathrm{~g} \mathrm{~kg}^{-1}$ 이었다. 10 월에 채취한 대추 잎의 평균 $\mathrm{T}-\mathrm{N}$ 은 $18.6 \mathrm{~g} \mathrm{~kg}^{-1}, \mathrm{P}$ 는 $2.4 \mathrm{~g} \mathrm{~kg}^{-1}, \mathrm{~K}$ 은 $17.3 \mathrm{~g} \mathrm{~kg}^{-1}, \mathrm{Ca}$ 는 $17.7 \mathrm{~g} \mathrm{~kg}^{-1}$, $\mathrm{Mg}$ 은 $2.3 \mathrm{~g} \mathrm{~kg}^{-1}$ 이었다. 7 월에 채취한 잎의 $\mathrm{T}-\mathrm{N}, \mathrm{K}$ 및 Mg 은 10 월에 채취한 잎보다 다소 높았으며, $\mathrm{P}$ 및 $\mathrm{Ca}$ 는 비슷한 경향이었다. Kim et al. (2011)은 10월에 채취한 대추 잎의 $\mathrm{P}$ 는 $2.9 \mathrm{mg} \mathrm{kg}^{-1}$, K은 $17.1 \mathrm{mg} \mathrm{kg}{ }^{-1}, \mathrm{Ca}$ 은 $32.5 \mathrm{mg} \mathrm{kg}^{-1}$, $\mathrm{Mg}$ 은 $1.6 \mathrm{mg} \mathrm{kg}^{-1}$ 로 보고하였다. 본 조사에서의 결과는 $\mathrm{Kim}$ et al. (2011) 결과와 비교하여 $\mathrm{Ca}$ 함량이 적었다. 이와 같은 결과는 시비방법 및 시비량에 따라 차이가 있을 것이 라 사료되므로 좀 더 연구가 수행되어야 할 것이다. 10 월에
$80 \%$ 정도 완숙된 대추 과실의 무기성분 함량 및 과실의 당도 를 조사하였다 (Table 3). 대추 과실의 평균 T-N은 $4.6 \mathrm{~g} \mathrm{~kg}^{-1}$ 이었고, $\mathrm{P}$ 는 $1.3 \mathrm{~g} \mathrm{~kg}^{-1}$ 이었으며, $\mathrm{K}$ 은 $8.6 \mathrm{~g} \mathrm{~kg}^{-1}$, $\mathrm{Ca}$ 은 0.5 $\mathrm{g} \mathrm{kg}^{-1}, \mathrm{Mg}$ 은 $0.6 \mathrm{~g} \mathrm{~kg}^{-1}$ 이었다. 과실에 대한 당도는 28.2 ${ }^{\circ} B r i x$ 였다. Kim et al. (2011)은 10월에 채취한 대추 열매의 $\mathrm{P}$ 의 함량은 $1.7 \mathrm{~g} \mathrm{~kg}^{-1}, \mathrm{~K}$ 은 $9.0 \mathrm{~g} \mathrm{~kg}^{-1}, \mathrm{Ca}$ 은 $0.7 \mathrm{~g} \mathrm{~kg}^{-1}$, $\mathrm{Mg}$ 은 $0.3 \mathrm{~g} \mathrm{~kg}^{-1}$ 이라고 보고하였다. 본 조사의 결과는 Kim et al. (2011)의 보고 결과와 비교하여 $\mathrm{Mg}$ 함량을 제외하고 는 전반적으로 다소 낮았다. 이것은 과실의 숙성정도 및 토 양 양분 등 여러 가지 요인에 의한 것이라 사료된다. 본 조 사결과, 대추 잎에 대한 무기 성분함량은 시기별로 상당히 다르며, 과실의 무기성분 함량에 비하여 높다는 것을 알 수 있다. 대추 잎의 무기성분 함량 중 $\mathrm{K}$ 및 $\mathrm{Ca}$ 의 성분은 사과 (Park et al., 2000), 복숭아 (Seo et al., 2002) 잎의 무기성 분 함량에 비하여 상당히 높다. 따라서 대추 잎을 기능성 식 품 소재로 활용한다면 좋은 소재가 될 수 있을 것이라고 본 다. 아직 대추 잎의 양분함량에 대한 기준치가 마련되어 있 지 않기 때문에 본 연구에서 조사된 무농약재배로 인증된 대추 잎의 양분 함량에 대한 과부족을 판단하기는 어렵다. 따라서 향후 대추 잎의 영양성분을 분석하여 양분의 과부족 을 판단할 수 있는 기준이 마련될 수 있도록 많은 연구가 수 행되어야 할 것이다. 지금까지의 조사 결과에 의하면 보은 지역 무농약재배 인증농가의 과원에 대한 토양 양분함량은 각 조사 지점별로 매우 달랐으며, 평균 유효인산 함량은 적 정 치에 비하여 상당히 높았다. 대추 잎 및 과실의 무기성분 함량은 전반적으로 Kim et al. (2011)보고한 관행 재배 결과 와 특별한 차이가 없었다. 따라서 무농약인증재배시 관행 재배에 비하여 양분이 부족할 것이라고 판단하여 투입자재 를 과다 시용하지 말아야 한다. 또한, 토양 및 투입자재의 양분함량을 분석하여 적정량을 시비함으로서 토양중에 양 분이 과다 축적되지 않도록 적절하게 관리할 필요가 있다고 본다.

Table 2. Macro-nutrient contents of leaves of pesticide-free cultivated jujube trees.

\begin{tabular}{|c|c|c|c|c|c|}
\hline Sampling period & $\mathrm{T}-\mathrm{N}$ & $\mathrm{P}$ & K & $\mathrm{Ca}$ & $\mathrm{Mg}$ \\
\hline & \multicolumn{5}{|c|}{ - } \\
\hline Jul. & $26.1 \pm 5.74^{\dagger}$ & $2.2 \pm 0.42$ & $23.2 \pm 2.76$ & $17.7 \pm 1.91$ & $3.1 \pm 0.33$ \\
\hline Oct. & $18.6 \pm 1.79$ & $2.4 \pm 1.04$ & $17.3 \pm 4.20$ & $17.7 \pm 2.64$ & $2.3 \pm 0.21$ \\
\hline
\end{tabular}

$\dagger$ Average \pm standard deviation.

Table 3. Nutrient and sugar contents in mature jujube fruits.

\begin{tabular}{cccccc}
\hline \hline $\mathrm{T}-\mathrm{N}$ & $\mathrm{P}$ & $\mathrm{K}$ & $\mathrm{Ca}$ & $\mathrm{Mg}$ & Sugar content \\
\hline$-0-1.3 \pm 0.11$ & $8.6 \pm 0.55$ & $0.5 \pm 0.05$ & $0.6 \pm 0.03$ & ${ }^{\mathrm{b}}$ brix \\
$4.6 \pm 0.48^{\dagger}$ & $1.03 .2 \pm 1.4$ \\
\hline
\end{tabular}

${ }^{\dagger}$ Average \pm standard deviation 


\section{Conclusions}

대추 무농약재배 과원의 적절한 양분관리를 위한 기초자 료를 얻고자 보은군 일원 무농약재배인증 과원 9지점에서 2012년 7월과 10월에 토양과 대추 잎 및 과실을 채취하여 화학성을 조사하였다. 7 월과 10월에 조사된 토양의 유효인 산의 적정범위 (300 400 mg kg-1)분포율은 각각 $11 \%$ 및 $33 \%$ 이었으며, 적정범위 이상의 분포율은 7월과 10월 모두 $56 \%$ 이었다. 치환성 $\mathrm{K}$ 이온의 적정범위 $\left(0.4 \sim 0.8 \mathrm{cmol}_{\mathrm{c}} \mathrm{kg}^{-1}\right)$ 분 포율은 7월과 10월 모두 $44 \%$ 이었고, 치환성 $\mathrm{Ca}$ 이온의 적 정범위 $\left(4.0 \sim 7.0 \mathrm{cmol}_{\mathrm{c}} \mathrm{kg}^{-1}\right)$ 분포율은 $67 \%$ 이었으며, 치환성 $\mathrm{Mg}$ 이온의 적정범위 $\left(1.0 \sim 2.0 \mathrm{cmol}_{\mathrm{c}} \mathrm{kg}^{-1}\right)$ 분포율은 7월 및 10 월에 각각 $100 \%$ 및 $56 \%$ 이었다. 대추 잎의 무기성분 함량 은 과실의 무기성분 함량 보다 높았으며, 7 월에 채취한 잎 의 $\mathrm{T}-\mathrm{N}, \mathrm{K}$ 및 $\mathrm{Mg}$ 은 10 월에 채취한 잎보다 높았다.

\section{References}

An, D.S. and D.S. Lee. 1997. Effect of maturity and storage temperature on preservation of fresh jujube. Korean J. Food Sci. Technol. 29:758-763.

Bak, W.C. and Y.J. La. 1993. Control of jujube witches'-broom by post-harvest trunk injection of oxytetracycline. Jour. Korean For. Soc. 82:12-16.

Choi, H.S. X. Li, W.S. Kim, Y. Lee, and H.J. Jee. 2011. Comparison of soil physico-chemical and microbial characteristics in soil of 'Niitaka' pear orchards between organic and conventional cultivations. Korean. J. Organic Argri. 19:229-243.

Choi, K.Y. H.D. H. Lee, Y.Y. Song, J.C. Nam, and S.W. Lee. 2010. Current status on the occurrence and management of disease, insect and mite pests in the non-chemical or organic cultured apple orchards in Korea. Korean. J. Organic Argri. 18:221-232.

Chung, D.S., Y.K. Son, N.K. Park, and Y.B. Kim. 1995. Studies on C. A storage of chinese jujube (Zizyphus jujuba Miller) and tomato (Lycopersicum esculentum Mill). RDA. J. Agri. Sci. 36:702-708.

Hong, J.Y., H.S. Nam, and S.R. Shin. 2010. Changes on the antioxidant activities of extracts from the Ziziphus Jujube Miller fruits during maturation. Korean J. Food Preserv. 17:712-719.

Hong, J.Y., H.S. Nam, and S.R. Shin. 2012. Physicochemical properties of rip and dry jujube (Ziziphus jujuba Miller) fruits.
Korean J. Food Preserv. 19:87-94.

Jee. H.J., Y.S. Lim, K.C. Jung, and W.D. Cho. 1998. Phytophthora citricola, a causal agent of jujube (Zizyphus jujuba) fruit rot. Korean J. Plant Pathol. 14:42-407.

KFS. 2012. Production survey of forest products in 2011. p. 27. Kim, D.I., S.G. Kim, S.J. Ko., B.R. Kang, D.S. Choi, G.H. Lim, and S.S. Kim. 2011. Biodiversity of invertebrate on organic and conventional pear orchards. Korean. J. Organic Argri. 19:93-107.

Kim, H.H., C.H. Jeong, S.J. Park, and K,H. Shin. 2011. Nutritional components and antioxidative activities of jujube (Zizyphus jujuba) fruit and leaf. Korean J. Food Preserv. 18:341-348.

Kim, J.K., Y.T. Jung, I.S. Son, and E.S. Yun. 1989. Cultivation status and characteristics of the jujube (Zyzyphus jujuba M.) cultivation soils in the chief producing district of Yeongnam area. Res. Rept. RDA (S\&F). 31:29-36.

Kim, Y.S., J.S, Yun, M.S. Yiem, K.H. Hong, and W.S. Kim. 1988. A new jujube cultiva "Wolchul" for fresh and dry fruit. Res. Rept. RDA(H). 30:89-92.

Kim, Y.S., K.H. Hong, and W.S. Kim. 1980. Survey of distribution and characteristics of local strains of Zyzyphus jujuba Miller in Korea. Res. Rept. RDA. 22:45-55.

Kim, Y.S., K.H. Hong, and W.S. Kim. 1981. The selection of local jujube cultivars (Zyzyphus jujuba M.). Res. Rept. RDA. 23:24-33.

La, Y.J. and D.J. Lee. 1984. Distribution of mycoplasma in witches'-broom infected jujube tissue. Jour. Korean For. Soc. 67:28-30.

NIAST. 2000. Methods of soil and plant analysis. National Institute of Agricultural Science and Technology, Rural Development Administration, Suwon, Korea.

Park, H.W., J.F. Guan, S.H. Kim, H.S. Cha, H.R. Park, and Y.H. Kim. 2006. Development of functional modified atmosphere film for winter date. Korean J. Food Preserv. 13:125-130.

Park, J.M., H.M. Ro, M.S. Yiem, and Y.J. Yim. 2000. Short-term effect of orchard floor management on soil chemical properties, growth and fruit quality in 'fuji/M.26 apple trees. J. Kor. Soc. Hort. Sci. 4:169-172.

Seo, Y.J., J.S. Kim, J.K. Kim, J.U. Cho, T.Y. Kwon, and J.S. Lee. 2002. Soil chemical properties of peach orchard and nutrient content of peach leaves in Gyeongbuk area. Kor. J. Soil Sci. Ferti. 35:175-184.

Shin, S.R., J.P. Han, S.H. Lee, M.J. Kang, K.S. Kim, and K.H. Lee. 1999. Changes in the components of dried jujube fruit by drying methods. Korean J. Postharvest Sci. Technol. 6:61-65. 